Volume 6 Issue 4, December 2019

Nationally Accredited Journal,

Decree No. B/4130/E5/E5.2.1/2019

\title{
Collection Of Non Tax State Revenue (Non-Tax) In The Sale Of Land By Law No. 9 Of 2018 In The Office Of National Land Agency In Semarang City
}

\begin{abstract}
Kirana Asmitha Dewi ${ }^{1}$ and Maryanto ${ }^{2}$
Abstract. The purpose of this study was to: 1) To determine the form of non-tax state revenues (non-tax) in the transfer of land rights under Act No. 9 in 2018 at the National Land Agency of Semarang. 2) To determine the barriers and solutions in implementing the collection of non-tax state revenues (non-tax) in the National Land Agency of Semarang In the transition of land rights. The approach in this study is empirical juridical approach, the specification is descriptive analytical research, data needed includes primary and secondary data, taken with the population and sampling methods, and methods of data analysis using qualitative descriptive.

Based on the results of data analysis concluded that: 1) Lodging Tax State Revenue for the transfer-usually collected through intermediaries Deed Official Land (PPAT), although the edges remain submitted to the National Land Agency, and it could have been through a formula or a look of Value Zone Land is there, but at the time of calculation Land Deed official typically does not have any land value zone or commonly called Zoning Value of Land, it is estimated only through the ground's Value Zone only. Because all for the sake of security clien to avoid underpayment. And with the Non Tax Revenue This brings several benefits to the State, the institutions and the community itself; 2) For the collection held Non Tax Revenue is expected for all types of community service to work optimally. For the barriers that still exist both from National Land Agency and of the community itself, for the BPN as placeholders pay Non Tax Revenue to be paid to the State Treasury accounted for the maximum, and the form must be appropriate and clear amount. And keep holding the socialization of non-tax revenues.

Keywords: State Revenue Tax; Transfer of Land Rights; Purchase.
\end{abstract}

\section{Introduction}

Indonesia has diverse names or designations, depending on the viewpoint of the expert assessment results in a variety of disciplines. Some call that Indonesia as a developing country, the modern welfare state, a state of law, and part of it. Although it has a wide range of titles, in relation to this assessment, the State of Law is the most appropriate naming used for any act or acts committed by maintenance compulsory under the applicable law.

Crate as Tax Revenue is the most potent of revenues for the country, because the tax rate in line with the rate of population growth, economy, and political stability. Acceptance of such a tax outside of the oil and gas sector in accordance with the laws of nature, if constantly exploited tend to be reduced and will eventually run out. Taxes

\footnotetext{
${ }^{1}$ Student Master of Notary Program, Faculty of Law, Sultan Agung Islamic University Semarang email: kiranaasmitha1@gmail.com

${ }^{2}$ Faculty of Law, University Islam Sultan Agung Semarang
} 
are one source of cash income countries is used for development with the ultimate goal of welfare and prosperity of the people. Taxes are the most potential revenue flows to the country, because the tax rate in line with the rate of population growth, economic and political stability. Taxes can also be interpreted as a contribution to the state (which can be enforced), ${ }^{3}$

If there are allegations of misuse of state finances of state revenue tax, legal action shall be justified by Law No. 9 of 2018. The legal action was in the form of examination conducted by the competent authority. Examination of a series of activities to search, collect, process data, or other information in order to control the fulfillment of obligations required to pay obedience and government agencies appointed by the minister of finance is based on the legislation in the field of non-tax income applicable.

Implementation of the examination should not deviate from the terms on which it is so it does not cause any harm to the examination. This is because the irregularities that occurred in the implementation of the inspection is illegal and may even result in the examinations may be canceled. This is due, investigations remain guided by openness and honesty that Act No. 92018 can be enforced without going through the court process. $^{4}$

Therefore, of the exercise of Non Tax Revenue or abbreviated to PNBP until now there has been running perfectly, there are flaws in this implementation. It shall pay Notary Deed Official Land or already implementing its obligations to pay non-tax revenues, but unfortunately not all agencies actually deposit the Non Tax Revenue to the State Treasury. There is a direct use nontax state revenue funds and others.

Based on the background mentioned above, the authors are interested in doing further research to be formulated in the form of study, entitled Implementation Harvesting Tax State Revenue (non-tax) in Case of Sale and Purchase of Land Based on Law No. 9 Year 2018 In the National Land Agency City Semarang.

\section{Research methods}

The approach used in this study mainly by the method of empirical juridical approach in this research means is that in analyzing the problems made by combining the ingredients of the law (which is a secondary data) with the primary data collected in the field is about collecting state revenues tax Office of the National Land Agency Semarang. This approach is implemented by conducting direct research of the respondents and source in the field with the aim to collect objective data, which is referred to as primary data.

\section{Results and Discussion}

\subsection{Forms of Non Tax Revenue (non-tax) in the transfer of land rights under Act No. 9 in 2018 at the Land Office of Semarang}

\subsubsection{The procedure of depositing Non Tax Revenue}

${ }^{3}$ R. Santoso Brotodiharjo, 1987, Pengantar IImu Hukum Pajak, print.3, Gresco Bandung, Bandung, p.2

${ }^{4}$ Ibid, p.103-104 
Volume 6 Issue 4, December 2019

Nationally Accredited Journal,

Decree No. B/4130/E5/E5.2.1/2019

Based on interviews with Mrs. Lila Trisnaningsih, S.ST female employee of the National Land Agency (BPN) in Semarang can be obtained information that:

The legal basis for the determination of Non Tax Revenue in the Regulation of the Minister of Agrarian and Spatial Planning / Head of National Land Agency of the Republic of Indonesia Number 14 of 2016 concerning Governing Terms and procedure for the imposition of tariffs PNBP against certain parties, bearing in mind Act No. 20 of 1997 on Non Tax Revenue, Government Regulation No. 22 of 1997 on type and Payment of Non Tax Revenue, Government Regulation Number 128 of 2015 about the type and Tariff on type Tax State Revenues Applicable within the Ministry of Agricultural and spatial Planning, the Presidential Decree No. 172015 of the Ministry of Agricultural and Spatial Planning, the Presidential Decree Number 20 of 2015 concerning the National Land Agency

In applying the non-tax revenue rates applicable, the National Land Agency to use a computer application program. applications that use so-called "Computerized Land Office (NOA)." Output (output) of these applications which include Warrant Deposit (SPS), receipts, and a letter of assignment. The application design is programmed to perform the calculation of non-tax rate automatically according to the type of land services activities and the applicable rate, but the rate calculation is not displayed on the output, both SPS and receipts.

In fact, the entire deposit liabilities Non Tax Revenue to the State Treasury including the Non Tax Revenue from Particular Activities that can be used by the state ministries / agencies that picked / manage it.

Regulation No. 13 of 2010 regarding Type and Tariff on Payment of Non Tax Revenue in force at the National Land Agency, Article 26 states "All Non Tax Revenue in force at the National Land Agency must be deposited directly as soon as possible to the State Treasury." All these provisions states must be paid directly to the State Treasury as soon as possible. The use of the word "immediately" herein is meant that the Non Tax Revenue Receipts received by the Treasurer on a weekday to be deposited on the same day to the State Treasury. Of course, such an interpretation is not correct because the hours of service of the state ministries / agencies that manage State Revenue Tax is generally longer than the hours of service Bank / Perception Post that accepts deposits to the account of the State Treasury. A more precise interpretation of the word "immediately" is on the following working day. National Land Agency which has the function of providing land services has a working area that extends across the island and archipelago in the sovereign territory of the Republic of Indonesia. The latest innovation developed programs BPN lately is the People's Program for Land Certification Service (Larasita) which is a mobile front office services online. With this program, land owners no longer need to deliver files it has land to the Land Office for the officer will come to the applicants in their villages ranging from file preparation, payment of fees, up to receive certificates that have been processed. ${ }^{5}$ In addition, the importance of non-tax revenues to the State Treasury deposits, especially at the end of the fiscal year, is to order the administration of non-tax revenues in the management of state finances. This relates to the preparation of the Budget Realization Report

\footnotetext{
${ }^{5}$ BPN RI, "Larasita Socialization Communication Forum Bakohumas," bhumibhakti, Issue 10,
} hal.40 
(LRA) were prepared using basic cash (cash basis), which means the realization of revenue and expenditure budget is prepared by cash manifestly to the account of the State Treasury or out of the State Treasury. When depositing non-tax revenues to the State Treasury has been far in respect of the fiscal year, then it has violated the principle of periodicity in state financial management for non-tax receipts which is actually a realization of the budget in a given fiscal year are reported as the realization of the budget in the next fiscal year. Therefore,

National Land Agency of Semarang is an element of the implementation of local government and the state revenue sector financial management center. National Land Agency of Semarang has limited authority to manage the Non Tax Revenue as well as possible, plan what is to be issued disbursement for budget in BPN and the rest must be submitted to the State Treasury. It is true that the Non Tax Revenue also be legally used for the budget office but not used things that go into a person but for in terms of the purposes of ATK, Procurement- socialization and the like.

\subsubsection{Harvesting Implementation of Non Tax Revenue}

Based on interviews ${ }^{6}$, Obtained information that in order to determine the amount of the specified non-tax revenues given to the mandatory pay itself with the help of his PPAT.

Mandatory pay does not participate in the case of calculating the amount of the specified non-tax revenues, Depositor will be deposited by the office staff PPAT itself so shall pay does not participate actively. Lodging Tax State Revenue for the transferusually collected through intermediaries Deed Official Land (PPAT), although the edges remain submitted to the National Land Agency, and it could be through a formula or a look of Value Zone Land is there, but at the time of calculation is usually Land Deed official ZNT not filed or commonly called Zoning Value of Land, it is estimated only through the ground's Value Zone only. Because all for the sake of security clien to avoid underpayment.

For example: Non-tax rates of application example based SPS, receipts and letters of assignment compared to the application of non-tax rates based on the calculation formula manually, there are some things that need to be further discussed, namely: a. Surveying Services, Measurement Limit or Boundary Region, and Mapping.

In the example of the imposition of tariffs PNBP for Measuring and Mapping Service Activity Parcel by the applicant on behalf of Cory Richi Sembiring, rates charged as specified in the warrant Deposit (SPS) is in accordance with the tariff formula for the area of land up to 10 hectares, namely:

$$
\mathrm{Tu}=\left(\begin{array}{l}
\mathrm{L} \\
500 .
\end{array}\right.
$$

According to Article 20 of Government Regulation No. 13 of 2010.

Surveying Services, Measurement Limit or Boundary Region, and the mapping is one type of land services the cost of transportation, accommodation, and consumption for measuring officers charged to the applicant / mandatory pay. By looking at the amount to be paid arrangement and as contained in the SPS, it can be concluded that the cost of transportation, accommodation, and consumption activities Measuring and Mapping

\footnotetext{
${ }^{6}$ Results of interviews with Mrs. Notary Irawati Asrining Dyah Pratiwi, as Notary PPAT in Semarang on December 2, 2019
} 
Volume 6 Issue 4, December 2019

Nationally Accredited Journal,

Decree No. B/4130/E5/E5.2.1/2019

Services Land Parcels are not counted as non-tax revenues, so that the Treasurer reception does not pick it up.

Land Registry include the Land Registry Services for the First Time and Maintenance Services Land Register data.

Service Land Register for the First Time In the example of the application of tariff PNBP activities Enrollment Services Decree Extension of Land for Building Rights by the applicant on behalf of Goey Sin Lian / Enny Gunawan, rates charged as specified in the warrant Deposit (SPS) is in accordance with the tariff formula:

$\mathrm{T}=$ (2\%o $\mathrm{x}$ Value of Land) + Rp 100.000, - .

In addition, the applicant is also subject to tariffs in accordance with Annex Regulation No. 13 of 2010 are shown in the Table.

Services Maintenance of Land Register data In the example of the application of tariff PNBP activities Enrollment Services Transfer of Transfer of Rights to Land for Individuals and Legal Entities with the applicant on behalf of Faith / Angga Setiawan, rates charged as specified in the warrant Deposit (SPS) is in accordance with the the tariff formula: $T=(1 \%$ o Value of Land $)+R p 50.000$, -. In addition, the applicant is also subject to tariffs in accordance with Annex Regulation No. 13 of 2010 are shown in the table.

In the example of the application of non-tax rates for the activities of the Land Inspection Service, the tariff formula PNBP for Land Inspection Service activities by Committee $A$ as follows:

$\mathrm{Tpa}=(\underset{500}{\mathrm{~L}} \mathrm{-----}$ x HSBKpa $)+$ Rp 350.000,-

Besides, as for the benefit of the Non Tax Revenue includes:

Benefits to the State, That not only tax as state revenues that must be deposited into the state treasury, but also all non-tax revenue. Depositing non-tax revenue to the state treasury management is intended to remain in the system of income and expenditure budget. System budget revenue and expenditure is a way to regulate the entrance and exit of state finances by the procedure specified. The system is to determine the government to determine the use of non-tax reception for the state and shall be accountable to the House of Representatives. Therefore, the presence of nontax state revenue, which is one source of state revenue, then the state revenue increasing and could be used for the purposes for this country, especially shopping state. Non-tax revenue so that at any time can be used to finance the implementation of state goals as embodied in the Fourth Alenia preamble of the Constitution of 1945. Its use must not conflict with the legislation in force in the field of non-tax revenue. For example, for relocations, repair and construction of highways or toll roads, and other some of it. Its use must not conflict with the legislation in force in the field of non-tax revenue. For example, for relocations, repair and construction of highways or toll roads, and other sebagainnya. Its use must not conflict with the legislation in force in the field of non-tax revenue. For example, for relocations, repair and construction of highways or toll roads, and other some of it.

Benefits to Society, That the presence of non-tax revenue of the state revenue is also growing, therefore any environmental or public services can be improved and the maximum in serving the community. Due to the presence of non-tax revenue is people 
feel more hopeful optimization of public services today, a small example with their ministry of health insurance in the hospital, in terms of education and training are often held by the government so that if there are people who unable to attend school or course of study will be held free of charge and the benefits will be felt by the community itself, and many other examples that could be perceived by the public.

Benefits for Agencies, With the non-tax revenue, the agency only bridge between the people or subjects paid by the state. All will be deposited for the purposes of the state. Only the presence of non-tax revenue could help the agency in terms of shopping stationery, and the like.

In addition to the benefits of this state revenues will be charged equally fairly and without discriminating, almost anyone, anytime, and anywhere we proceed will certainly incur non-tax revenue and is held for all of society. Both individuals and institutions.

\subsection{Obstacles and solutions related to the collection of the Tax State Revenue (non-tax) in the National Land Agency of Semarang In the transition of land rights.}

Barriers of the National Land Agency to the State treasury which in depositing Non Tax Revenue to the State Treasury there are some problems such as late deposit to the State Treasury, that BPN is required to deposit by a specified time, but the reality is still problem late payment, and in the collection of Acceptance Tax state no clear agreement magnitude. So this could be a very severe problem because the State there is no certainty the amount set out therefore how the state will conduct oversight if the amount of course there is no clear certainty.

Besides, the obstacles that arise from the people are objections. Where mind This could be experienced by the public, with this objection is that citizens can file an objection by attaching a letter from the Chairman of RT / RW and known by the village chief, village head, or any other name, and the people involved in the government program of housing is simple, can attach a certificate or a decision on membership is concerned in the Government Program of the Department of housing Ministry charge of housing.

And regarding the administration should also be well prepared and neatly so the implementation was clear and if there would be a clear oversight. The magnitude of the uncertainty is still very minimal supervision and has not been maximized.

The solution of the above items should be a determination of the amount of charges adjusted to cost of services and the burden on society. There should be curbing charges fabricated through Human Resources assigned as supervision, so that the implementation of the Non Tax Revenue can be optimized and realized. And must be confirmed on the sanctions if no deposit or late deposit.

The response of the clien? ${ }^{7}$, Who came to the Deed Official Land (PPAT) that there is still a lot of clien which still did not fully understand what the Non Tax Revenue, in fact there are many who think that the Non Tax Revenue abbreviated to non-tax revenues paid by PPAT will be entered into PPAT his, Though not, PPAT only as an intermediary between the deposit of non-tax revenues. Therefore, the existence of such cases is

\footnotetext{
${ }^{7}$ Results of interviews with Muhsyid, as the community respondents, on December 5, 2019
} 
Volume 6 Issue 4, December 2019

Nationally Accredited Journal,

Decree No. B/4130/E5/E5.2.1/2019

expected that the government should hold a first dissemination of the Tax State Revenue (non-tax) so that people know and understand.

\section{Closing}

\subsection{Conclusion}

Based on the research results can be drawn as follows:

- Lodging Tax State Revenue for the transfer-usually collected through intermediaries Deed Official Land (PPAT), although the edges remain submitted to the National Land Agency, and it could have been through a formula or a look of Value Zone Land is there, but at the time of calculation Land Deed official typically does not have any land value zone or commonly called Zoning Value of Land, it is estimated only through the ground's Value Zone only. Because all for the sake of security clien to avoid underpayment. And with the Non Tax Revenue This brings several benefits to the State, the institutions and the community itself.

- With the non-tax state revenue has not run optimally, so there must be some rules and systems are modified so that it runs with optimal collection.

\subsection{Suggestion}

- For the collection holding Non Tax Revenue is expected for all types of community service to work optimally.

- For the barriers that still exist both from National Land Agency and of the community itself, for the BPN as placeholders pay Non Tax Revenue to be paid to the State Treasury accounted for the maximum, and the form must be appropriate and clear amount. And keep holding the socialization of non-tax revenues

\section{References}

\section{Books:}

[1] Kaeelan MS 2005, Metode Penelitian Kualitatif Bidang Filsafat, Jakarta: Grafindo

[2] Djafar Muhammad Saidi, and Rohana Huseng, 2008, Hukum Penerimaan Negara Bukan Pajak, Jakarta: PT. RajaGrafindo Persada

[3] R. Santoso Brotodiharjo, 1987, Pengantar Ilmu Hukum Pajak, print.3, Bandung: Gresco Bandung

[4] Ronny Hanitijo Soemitro, 1998, Metodologi Penelitian Hukum, Jakarta: Indonesian Hlia,

[5] Soerjono Soekanto, 1996, Pengantar Penelitian Hukum, Jakarta: Rineka Reserved

[6] Sudikno Mertokusumo 2005, Mengenal Hukum Suatu Pengantar, Yogyakarta: Liberty

[7] Suparmoko, 1991, Metode Penelitian Praktis, Yogykarta

\section{Internet:}

[1] http://www.bpkp.go.id/perekonomian/konten/263/penerimaan-negara-bukanpajak.bpkp 
[2] http://mangihot.blogspot.com/2017/02/pengertian-jual-beli-tanah-menurut.html

[3] https://id.scribd.com?document/353957728/Teori-Kepastian-Hukum

[4] https://www.academia.edu/10691642/Keadilan Kepastian

[5] https://mirdinatajaka.blogspot.com/2017/05/teori-keadilan-hukum.html 